\title{
Current course of trams approval process in Poland. Problems related to interpretation of regulations concerning the technical specifications of trams.
}

\author{
Aktualny przebieg procesu homologacji tramwajów w Polsce. \\ Problemy związane $\mathrm{z}$ interpretacją przepisów dotyczących \\ warunków technicznych tramwajów
}

\begin{abstract}
The article discusses the current course of the trams approval process in Poland. It is indicated which documents the tram producer is obliged to provide to the authorized body and which tests are necessary to carry out in order to obtain the approval certificate. Inaccuracies resulting from the regulations in force and their interpretation are described, with particular taking into consideration the approval tests. The above issue is discussed in terms of practical application and a proposal for provisions regulating unspecified requirements concerning vehicle is placed in. In addition, the article brings up the issue of tightening the requirements for approval tests of trams with appropriate iustification.

$W$ artykule omówiono aktualny przebieg procesu homologacji tramwajów w Polsce. Wskazano jakie dokumenty producent tramwaju jest zobowiqzany dostarczyć jednostce upoważnionej oraz jakie badania sq konieczne do przeprowadzenia $w$ celu uzyskania świadectwa homologacji. Opisano nieścistości wynikajace z obowiqzujacych przepisów oraz ich interpretację, ze szczególnym uwzględnieniem badań homologacyjnych. Powyższe zagadnienie omówiono pod katem praktycznego zastosowania oraz zamieszczono propozycję zapisów regulujacych niesprecyzowane wymagania dotyczqce pojazdów. Ponadto poruszono kwestię zaostrzenia wymagań dotyczacych badań homologacyjnych tramwajów wraz z odpowiednim uzasadnieniem.
\end{abstract}

\section{Introduction}

It is assumed that the most reliable, mass means of urban transport is the tram. In Poland they are operated in larger cities or urban agglomerations. There are currently 15 places in our country that have an active tram infrastructure. Since 2015. the trams again have been in Olsztyn, where the new infrastructure was built. It is the only reactivated tram network in Poland [24]. In Europe a similar example can be found in Edinburgh, where after almost 60 years the new infrastructure was built and the new trams were put into operation [23]. Tram networks in cities differ from each other, for example in track gauge, gauge, but their approval process in Poland is the same for all vehicles. The documents that regulate the approval process are the Regulation of the Minister of Infrastructure on the technical conditions of trams and trolleybuses and the scope of their necessary equipment O. J. of 2011, No. 65, item 344 [1], and the Regulation of the Minister of Transport, Construction and Maritime Economy on the type

\section{Wstęp}

Przyjmuje się, że najbardziej niezawodnym, masowym środkiem transportu miejskiego są tramwaje. W Polsce eksploatowane są one w większych miastach lub aglomeracjach miejskich. Obecnie jest 15 miejsc w naszym kraju które posiadają czynną infrastrukturę tramwajową. Od 2015 r., tramwaje ponownie zawitały do Olsztyna, gdzie zbudowano nową infrastrukturę. Jest to jedyna $\mathrm{w}$ Polsce reaktywowana sieć tramwajowa [24].

W Europie podobny przykład możemy spotkać w Edynburgu, gdzie po niemal 60 latach również zbudowano nowa infrastrukture i wprowadzono do ruchu nowe tramwaje [23]. Sieci tramwajowe w miastach różnią się od siebie np. rozstawem torów, skrajnią, jednak ich proces homologacji w Polsce jest jednakowy dla wszystkich pojazdów. Dokumentami, które regulują proces dopuszczenia jest Rozporządzenie Ministra Infrastruktury w sprawie warunków technicznych tramwajów i trolejbusów oraz zakresu ich niezbędnego wyposażenia (Dz.U. 2011r., nr 65, poz. 
approval of trams and trolleybuses O. J. 2015., item 38 [2]. The first of these documents strictly defines the technical requirements that must be met by the vehicle. The second one defines the types of vehicles (type, version, variant), it specifies the procedure for conducting approval tests and checking the conformity of production. Moreover, the vehicle producer will find there the essential information concerning the preparation of approval documents.

\section{Course of tram approval process in Poland}

The course of the tram approval process largely depends on the type of vehicle that was delivered for testing. When the tram is a completely new construction with a new designation, with a new, different drive, then the approval of tram type is carried out. During this process the full range of tests and the analysis of all documents should be carried out. In the case when the changes are made in the configuration of type of tram that differ it from the original type, even in one of the aspects listed below, then it is not necessary to carry out the full approval of tram type, but only a type extension by a variant. The various constructional characteristics of the vehicle that allow to qualify the vehicle as a new variant of it:

- type of tram (motor, trailer active, trailer passive),

- tram directionality (one-directional or twodirectional),

- nominal power supply voltage,

- track gauge,

- bogies or chassis (essential constructional characteristics),

- driven axles (number, position, kinematic relation),

- axle system,

- type and kind of electric traction engines (direct current, asynchronous or synchronous),

- number of engines and traction converters,

- type and kind of traction converters,

- type and kind of braking systems (electrodynamic, rail, disc, jaw or eddy current brakes),

- type of autonomous drive system (battery, capacitor tank or capacitor tank with battery).

In case when these changes are even less significant than those mentioned above and include only one of the following characteristics:

- permissible total weight,

- nominal power of the traction drive,

- the largest number of seats,

- type and kind of gear,

- type and kind of devices operating under traction voltage, in particular the current pantographs, protection devices of excessive network circuits,
344 [1]) oraz Rozporządzenie Ministra Transportu, Budownictwa i Gospodarki Morskiej w sprawie homologacji typu tramwajów i trolejbusów (Dz. U. 2015r., poz. 38 [2]). Pierwszy z tych dokumentów ściśle określa wymagania techniczne, jakie musi spełnić pojazd. Drugi natomiast definiuje rodzaje pojazdów (typ, wersja, wariant), określa procedure przeprowadzania badań homologacyjnych oraz kontroli zgodności produkcji. Ponadto producent pojazdu znajdzie tam istotne informacje dotyczące przygotowania dokumentów homologacyjnych.

\section{Przebieg procesu homologacji tramwajów w Polsce}

Przebieg procesu homologacji tramwaju w dużej mierze zależy od rodzaju pojazdu, jaki został dostarczony do badań. Gdy tramwaj jest całkowicie nową konstrukcją o nowym oznaczeniu, z nowym, odmiennym napędem, wówczas przeprowadza się homologację typu tramwaju. Podczas tego procesu należy przeprowadzić pełen zakres badań i analizę wszystkich dokumentów. W przypadku, gdy $\mathrm{w}$ konfiguracji typu typu tramwaju zostały wprowadzone zmiany, które różnią go od pierwotnego typu chociażby w jednym $\mathrm{z}$ wymienionych poniżej aspektów, wtedy nie ma konieczności przeprowadzenia pełnej homologacji typu tramwaju, a jedynie rozszerzenie typu o wariant. Cechy konstrukcyjne pojazdu, które pozwalają na zakwalifikowanie pojazdu jako nowy wariant, to:

- $\quad$ rodzaj tramwaju (silnikowy, doczepny czynny, doczepny bierny)

- kierunkowość tramwaju (jednokierunkowy lub dwukierunkowy)

- $\quad$ nominalne napięcie zasilania

- $\quad$ szerokość toru

- wózki lub podwozie (istotne cechy konstrukcyjne)

- $\quad$ osie napędzane (liczba, położenie, powiązanie kinematyczne)

- układ osi

- $\quad$ typ i rodzaj silników trakcyjnych elektrycznych (prądu stałego, asynchroniczny albo synchroniczny)

- liczba silników i przekształtników trakcyjnych

- $\quad$ typ i rodzaj przekształtników trakcyjnych

- $\quad$ typ i rodzaj układów hamulcowych (elektrodynamiczne, szynowe, tarczowe, szczękowe lub zwalniacze wiroprądowe)

- $\quad$ rodzaj układu jazdy autonomicznej (akumulatorowy, zasobnik kondensatorowy albo zasobnik kondensatorowy z baterią akumulatorów).

W przypadku, gdy zmiany są jeszcze mniej istotne niż wymienione powyżej i obejmują, wyłącznie którąś z wymienionych cech:

- dopuszczalna masa całkowita

- nominalna moc napędu trakcyjnego

- największa liczba miejsc siedzących 
- type and kind of basic auxiliary equipment (converters, heating, engines of auxiliary drives),

- place of installation of traction converters, traction motors, converters, auxiliary engines,

- elements of the autonomic drive system,

- the power of an additional autonomous drive,

then the extension of the approval of the tram type with the variant $[1,2]$ is carried out.

In such cases, on the basis of the list of changes provided by the producer the authorized entity verifies the scope of tests and the necessary documentation. Then the full range of tests, which includes:

- $\quad$ stationary and operational tests concerning the tram equipment,

- measurement of static axle loads by particular tram axles,

- tests of acoustic properties of the tram,

- tests of the tram braking system,

- checking the handrail system in the tram,

- checking the elements of a safe glazing system in the tram,

- test of the electric wiring of the tram,

- tests of tram lighting,

- EMC tests of tram,

changes. The purpose of tests is checking whether the vehicle is produced in accordance

with technical requirements contained in O. J. 2011., No. 65 , item 344 [1]. In addition, the provided documents listed in the Regulation of the Minister of Transport, Construction and Maritime Economy are assessed and checked. It is checked, among others the certificates of approval for the used glazing in accordance with UNECE Regulation No 43, certificate of approval of the used external lighting in accordance with Annex No. 1 to O. J. 2015., item 38 [2]. Moreover, the authorized body, under the authority of the Transport Technical Supervision Director, carries out a conformity control of the production at producer to check whether it is able to ensure the reproducibility of the vehicle production process. This confirms the performance of each subsequent tram in the same configuration with the same parameters and technical specification as the approved version. After receiving the report of approval tests together with the protocol and other documents listed in article 70h paragraph 5 of the Road Traffic Law Act (O.J. 1997 No. 98 item 602) [3] the producer's of vehicle goes to Transport Technical Supervision that after the detailed analysis of documents, issues or refuses to issue a approval certificate of tram type [1, 2, 3, 8]. In the case of the used tram imported from abroad, there is no need to carry out the approval tests, and it is enough to perform only an extended technical test based on the Regulation of the Minister of Infrastructure on the scope, conditions, deadlines and way of carrying out the technical tests of trams and trolleybuses as well as the units performing
- $\quad$ typ i rodzaj przekładni

- $\quad$ typ i rodzaj urządzeń pracujących pod napięciem trakcyjnym, w szczególności odbieraki prądu, urządzenia zabezpieczeń nadmiarowych obwodów sieciowych

- typ i rodzaj podstawowych urządzeń pomocniczych (przetwornice, ogrzewanie, silniki napędów pomocniczych)

- miejsce zainstalowania przekształtników trakcyjnych, silników trakcyjnych, przetwornic, silników pomocniczych

- elementów układu napędu autonomicznego

- moc dodatkowego napędu autonomicznego,

wówczas przeprowadza się rozszerzenie homologacji typu tramwaju o wariant $[1,2]$.

W takich przypadkach, na podstawie dostarczonego przez producenta wykazu zmian, jednostka upoważniona dokonuje weryfikacji zakresu badań i niezbędnej dokumentacji.

W takim przypadku pełen zakres badań, w którego skład wchodzą:

- $\quad$ badania stacjonarne oraz ruchowe dotyczące wyposażenia

- pomiar nacisków statycznych wywieranych na tor przez poszczególne osie

- badania właściwości akustycznych tramwaju

- badanie układu hamulcowego

- $\quad$ sprawdzenie systemu poręczy w tramwaju

- $\quad$ sprawdzenie elementów bezpiecznego systemu oszklenia w

- $\quad$ badania instalacji elektrycznej tramwaju

- badania oświetlenia

- badania EMC

Badania mają na celu sprawdzenie, czy pojazd wyprodukowany jest zgodnie z wymaganiami technicznymi zawartymi w Dz. U. 2011 r., nr 65, poz. 344 [1].

Dodatkowo ocenie i sprawdzeniu podlegają dostarczone dokumenty wymienione w Rozporządzeniu Ministra Transportu, Budownictwa i Gospodarki Morskiej. Sprawdza się m.in. świadectwa homologacyjne zastosowanego oszklenia (zgodnie z Regulaminem EKG ONZ nr 43) i świadectwa homologacji zastosowanego oświetlenia zewnętrznego zgodnie z załącznikiem $\mathrm{nr} 1$ do Dz. U. 2015r., poz. 38 [2]. Ponadto jednostka uprawniona, $z$ upoważnienia Dyrektora Transportowego Dozoru Technicznego przeprowadza kontrolę zgodności produkcji u producenta w celu sprawdzenia, czy jest on w stanie zapewnić odtwarzalność procesu produkcji pojazdów. Potwierdza to wykonanie każdego kolejnego tramwaju w takiej samej konfiguracji, o takich samych parametrach i specyfikacji technicznej jak egzemplarz homologowany. Po otrzymaniu sprawozdania $z$ badań homologacyjnych wraz z protokółem oraz pozostałymi dokumentami wymienionymi w art. 70h ust. 5 ustawy Prawo o Ruchu Drogowym (Dz.U. 1997 Nr 98 poz. 602) [3] producent 
these tests O. J. 2011., No. 65, item 343 [5]. This solution is acceptable despite the change of the drive and other basic components of vehicle. However, these activities are less and less seen, and the Polish carriers put on the modern and more comfortable constructions.

\section{Approval tests - imprecision of regulations}

The scope of approval tests is depended on whether a given vehicle is a new type or an extension of an existing type with a variant or version. In the Regulation O. J. 2011., No. 65, item 344 [1] it is specified the requirement that must be met by the approved vehicle. However, not all records are precisely specified. This document does not define explicitly the requirements for several selected aspects, listed below:

\subsection{Electromagnetic compatibility.}

„Electrical and electronic devices should not emit excessive electromagnetic disturbances radiated to the environment."

The given requirement does not specify any standard according to which inspections should be performed. In such a case, when the requirements are not specified, the Rail Vehicles Institute as the approving unit may, based on its knowledge and experience, set standards that should be met by the vehicle in a given aspect. In this case, the PNEN 50121-3-1: 2017 [15] standard is accepted as valid for the approved trams. Its provisions are the basis for respecting this standard, which clearly define the vehicles that this standard applies to, including trams.

\subsection{Lighting of the driver's cab interior}

„, The cab of the driver's stand should be equipped with: (...) lighting of cab interior. "As in the above case in the Regulation $[1,2]$ it is not given any guidelines concerning the required intensity of lighting in the driver's cab. In the case of railway vehicles, it is given a number of restrictions which must be met by the driver's cab, from the intensity of lighting to the colours of the indicators lighting. In the case of trams, no specifications are specified which may worsen or improve visibility during driving, after nightfall. This issue can be treated in two ways, check the cab's lighting functionally or refer to a standard that includes lighting in the driver's cab in its records - PN-EN 13272: 2012 [12]. There it can be found the records that say about the need to provide lighting of 50 lux and 75 lux for the control desk. In relation with that the Regulation of the Minister of Transport, Construction and Maritime Economy (O.J. 2015., item 38) [2] says about measuring the level of illumination inside of the tram by the authorized unit, its functional measurement is appropriate.

\subsection{Trial run}

"The authorized unit carries out: (...) a trial run."

The provisions of the regulations $[1,2]$ do not specify the distance that the vehicle would ride to be able to reliably determine whether there are any leaks of operating pojazdu przekazuje dokumenty do Transportowego Dozoru Technicznego, który po szczegółowej analizie dokumentów wydaje lub odmawia wydania świadectwa homologacji typu tramwaju $[1,2,3,8]$. W przypadku tramwaju używanego, sprowadzonego z zagranicy nie ma konieczności przeprowadzania badań homologacyjnych, a wystarczy jedynie wykonać rozszerzone badanie techniczne w oparciu o Rozporządzenie Ministra Infrastruktury w sprawie zakresu, warunków, terminów i sposobu przeprowadzania badań technicznych tramwajów i trolejbusów oraz jednostek wykonujących te badania Dz. U. 2011 r., nr 65, poz. 343 [5]. Rozwiązanie to jest dopuszczalne pomimo zmiany napędu i innych podstawowych komponentów pojazdu. Działania te są jednak coraz rzadziej spotykane, a polscy przewoźnicy stawiają na nowoczesne i bardziej komfortowe konstrukcje.

\section{Badania homologacyjne - nieprecyzyjność prze- pisów}

Zakres badań homologacyjnych uzależniony jest od tego, czy dany pojazd jest nowym typem, czy rozszerzeniem istniejącego typu o wariant lub wersję. W Rozporządzeniu (Dz. U. 2011 r., nr 65, poz. 344 [1]) określono wymaganie, jakie musi spełniać homologowany pojazd. Nie wszystkie jednak zapisy są dokładnie sprecyzowane. Dokument ten nie definiuje jednoznacznie wymagań dotyczących kilku wybranych aspektów, wymienionych poniżej.

\subsection{Kompatybilność elektromagnetyczna.}

„Urzadzenia elektryczne i elektroniczne nie powinny emitować nadmiernych zaburzeń elektromagnetycznych promieniowanych do otoczenia."

Podane wymaganie nie precyzuje żadnej normy, wg której powinny być wykonane sprawdzenia. W takim przypadku, gdy wymagania nie są sprecyzowane, Instytut Pojazdów Szynowych jako jednostka homologująca w oparciu o swoją wiedzę i doświadczenie może wyznaczyć standardy, jakie powinien spełniać pojazd w danym aspekcie. W tym przypadku przyjęto, jako obowiązująca względem homologowanych tramwajów normę PN-EN 50121-3-1:2017 [15]. Podstawą do respektowania tej normy są jej zapisy, które jasno definiują pojazdy jakie obowiazzuje ta norma, w tym tramwaje.

\subsection{Oświetlenie wnętrza kabiny}

„Kabina stanowiska motorniczego powinna być wyposażona w: (...) oświetlenie wnętrza kabiny."

Podobnie, jak w powyższym przypadku, w Rozporządzeniach $[1,2]$ nie podano żadnych wytycznych dotyczących wymaganego natężenia oświetlenia w kabinie motorniczego. W przypadku pojazdów kolejowych podano szereg obostrzeń, jakie musi spełniać kabina maszynisty, od natężenia oświetlenia, po kolory podświetlenia wskaźników. W przypadku tramwajów nie określono specyfikacji elementów, które mogą pogorszyć lub polepszyć widoczność podczas jazdy, po zmroku. Tę kwestię można potraktować dwojako, czyli sprawdzić oświetlenie kabiny 
materials after the trial run. In this case the trial run can be called as the testing rides, which takes place during the test of brake (i.e. a specified number of rides from a speed of $30 \mathrm{~km} / \mathrm{h}$ on a small section of the track) as well as the long-distance ride which, more likely, can show some irregularities. The length of the trial run is often specified in the Specification of Essential Terms of Order of the company ordering the new vehicle. This is usually determined in the form of time that the vehicle must ride. For example, Warsaw Trams in its tender for the purchase of up to 213 new trams expects a new trial run to be no less than $18 \mathrm{~h}$ at $2 / 3$ of the nominal load and 1 hour with a nominal load [26]. Częstochowa in a tender for the supply of 10 new tram wagons requires that the trial run without passengers is $100 \mathrm{~km}$, while a trial run with passengers is $1000 \mathrm{~km}$ [27]. Like Warsaw, the Tramwaje Śląskie [28] requires the trial run in hours. For this company, the ride for the first tram must be 24 hours, and for each next 12 hours. In the case of the trial run being a check during the approval tests, specifying its distance

and specificity it should be taken into account, among others such criteria as: riding at maximum speed, target routes on which the vehicle is to move. It would be necessary to specify, taking into account all relevant conditions during the trial run, which would influence reveal any irregularities in the vehicle construction.

\subsection{Contrasting handrails and handles}

„, The surface of the handrail, handle or post must have a contrasting appearance

with the nearest surroundings and must be non-slip. " (UNECE No. 107, Annex 3) [6]. In this record, there is no information on how to check the contrast of rail vehicle components. In the case of railways, these records can be found, among others in the RFU PRM 053 recommendation [16] (issued by NB-Rail) to TSI PRM 1300/2014. This recommendation clearly defines the possibility of using elements with a specific RAL color keeping the essence of contrast between them (the contrast should be at least 0.3 calculated from the ratio of the difference in the luminance of the observed object and the luminance of the background to the sum of the two). This has the sensible justification because every person, who assesses with the naked eye, has a subjective feeling about contrast. This requirement should be clearly specified in the approval documents.

\section{Approval requirements and reality}

The above mentioned cases of unspecified provisions concerning approval tests are in actual fact the factors that do not directly threaten the safety of passengers and other traffic users. Due to the fact that relatively a large number of passengers traveling by the public transport, which, for example, is approx. 456 thousand in Szczecin per day (buses and trams) [25] and annually over 128 million only by trams, and in Olsztyn it is about 19 thousand passengers daily are carried only by trams. In many Polish cities there is a funkcjonalnie lub odnieść je do normy uwzględniającej w swoich zapisach oświetlenie w kabinie motorniczego norma PN-EN 13272:2012 [12]. Znaleźć tam można zapisy, które mówią o konieczności zapewnienia oświetlenia o natężeniu $50 \mathrm{~lx}$ oraz $75 \mathrm{~lx}$ dla pulpitu. W związku z tym, że Rozporządzenie Ministra Transportu, Budownictwa i Gospodarki Morskiej (Dz. U. 2015 r., poz. 38) [2] mówi o pomiarze poziomu natężenia oświetlenia wewnątrz tramwaju przez jednostkę uprawniona, stosowny jest chociażby jego pomiar funkcjonalny.

\subsection{Jazda próbna}

\section{„Jednostka uprawniona przeprowadza: (...) jazdę prób- nq."}

W zapisach rozporządzeń $[1,2]$ nie określono dystansu jaki miałby przejechać pojazd, aby rzetelnie określić, czy po jeździe próbnej nie występują np. wycieki materiałów eksploatacyjnych. W tym przypadku jazdą próbną można nazwać jazdy badawcze, które odbywają się przy okazji badań hamulca (czyli określonej liczby jazd z prędkości $30 \mathrm{~km} / \mathrm{h}$ na niewielkim odcinku torowiska), jak i jazdę długodystansową, która co bardziej prawdopodobne może wykazać pewne nieprawidłowości. Długość jazdy drogi próbnej często określana jest w Specyfikacji Istotnych Warunków Zamówienia przedsiębiorstwa zamawiającego nowy pojazd. Jest to określane zazwyczaj w postaci czasu trwania jazd próbnych pojazdu.

Dla przykładu, Tramwaje Warszawskie w swoim przetargu na zakup do 213 nowych tramwajów oczekują by jazda próbna trwała nie mniej niż 18 h przy $2 / 3$ obciążenia nominalnego i 1 godzinę $\mathrm{z}$ obciążeniem nominalnym [26]. Częstochowa w przetargu na dostawę 10 nowych wagonów tramwajowych wymaga, aby jazda próbna bez pasażerów wynosiła $100 \mathrm{~km}$, natomiast jazda próbna $\mathrm{z}$ pasażerami 1000 km [27]. Podobnie jak Warszawa swój wymóg jazdy próbnej wyrażony w godzinach określają Tramwaje Śląskie [28]. Dla tego przedsiębiorstwa jazda dla pierwszego tramwaju musi wynosić 24 godziny, a dla każdego następnego 12 godzin.

W przypadku jazdy próbnej będącej sprawdzeniem podczas badań homologacyjnych, określając jej dystans i specyfikę, należy wziąć pod uwagę m.in. takie kryteria jak: jazda z prędkością maksymalna, docelowe trasy, na których ma się poruszać pojazd. Należałoby określić, biorąc pod uwagę wszelkie istotne warunki podczas przeprowadzania jazdy próbnej, okoliczności wpływające na uwidocznienie ewentualnych nieprawidłowości w budowie pojazdu.

\subsection{Kontrastujące poręcze i uchwyty.}

„Powierzchnia poręczy, uchwytu lub stupka musi mieć wyglad kontrastujacy z najbliższym otoczeniem i musi być przeciwpoślizgowa." (EKG ONZ nr 107, załacznik nr 3) [6].

W zapisie tym brak jest jakichkolwiek informacji o sposobie sprawdzenia kontrastowości elementów pojazdów szynowych. W przypadku kolejnictwa zapisy te znaleźć można m.in. w zaleceniu RFU PRM 053 [16] (wydanym 


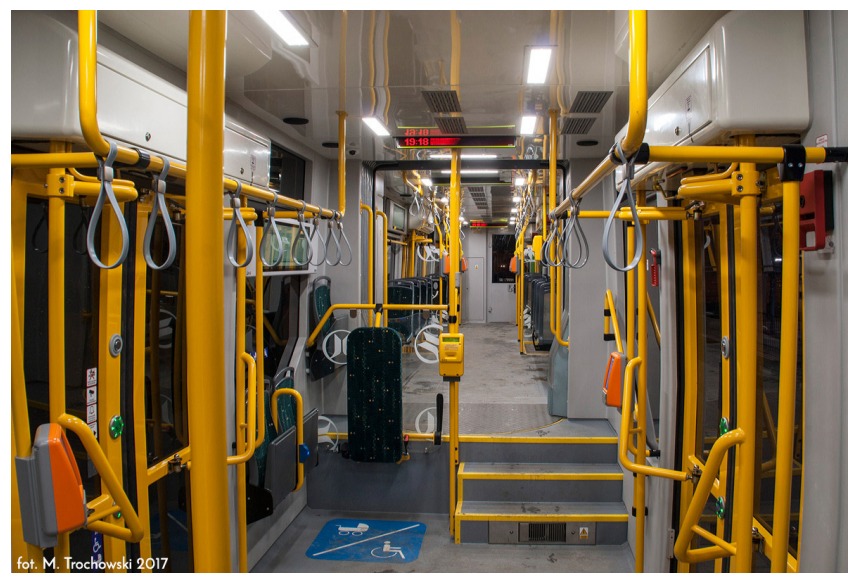

Fig. 1. View of the handrails in the tram MF $22 \mathrm{AC} B D$ contrasting with the nearest surroundings [22]

Rys. 1. Widok kontrastujących z najbliższym otoczeniem poręczy w tramwaju MF $22 \mathrm{AC} \mathrm{BD}$ [22]

greater interest in public transport in the form of trams due to continuous replacement and modernization for a newer, more comfortable rolling stock. Due to continuous replacement and modernization for a newer, more comfortable rolling stock. Due to the more and more advanced constructions and technical specifications of modern trams, it is necessary to adjust the existing approval requirements. According to the statistics of CSO (Central Statistical Office) [7] appears that in 2014. in Poland over 268 million passengers used the railway transport, but nearly 4 billion passengers used the public transport (including buses, trams, trolleybuses and metro). A part of the number of 4 billion are passengers of trams. This places them in the more often used means of transport than trains and electric multiple units, which have much more stringent requirements concerning approval tests than trams. This is an argument confirming the proposal to tighten or propose the additional approval requirements for trams in Poland. More often it is also found that carriers, that want to buy the new rolling stock, require to carry out the additional tests, besides the approval tests that meet the additional criteria. Below a few selected aspects, that are worth to pay attention and are not specified in regulations $[1,2]$ applied during the approval tests of trams, are presented. The purpose of this is only to signal gaps and develop them in the next works.

\subsection{Static, fatique strength and stability of body construction}

The regulations $[1,2]$ do not specify the requirements for the constructional strength of the tram body. Theoretically, the producer delivering the vehicle for approval tests has no obligation to provide the documents confirming the fulfillment of any standard concerning the constructional strength of the body. During operation the tram is subjected to static and dynamic loads. Therefore, it would be necessary to determine what loads should be able to withstand the load-bearing constructions of vehicles and what przez NB-Rail) do TSI PRM 1300/2014. Zalecenie to jednoznacznie określa możliwość stosowania elementów o określonym kolorze RAL zachowując istotę kontrastowości między nimi (kontrast powinien wynosić minimum 0,3 wyliczony ze stosunku różnicy luminancji obserwowanego obiektu i luminancji tła do sumy tych dwóch). Ma to sensowne uzasadnienie, ponieważ każda osoba oceniająca gołym okiem ma subiektywne odczucie dotyczące kontrastowości. Niniejsze wymaganie powinno być jednoznacznie określone w dokumentach dotyczących homologacji.

\section{Wymagania homologacyjne a rzeczywistość}

Przytoczone powyżej przypadki niesprecyzowanych przepisów dotyczących badań homologacyjnych są tak naprawdę czynnikami nie zagrażającymi bezpośrednio bezpieczeństwu pasażerów i innych uczestników ruchu. Komunikacją miejską podróżuje stosunkowo duża liczba pasażerów, która dla przykładu w Szczecinie wynosi ok. 456 tys. dziennie (autobusami i tramwajami) [25], a rocznie samymi tramwajami ponad 128 mln, natomiast w Olsztynie to ok 19 tys. pasażerów dziennie przewożonych wyłącznie tramwajami. W wielu polskich miastach notuje się większe zainteresowanie transportem zbiorowym $\mathrm{w}$ tym przejazdów tramwajami z uwagi na ciagła wymianę i modernizacje na nowszy, bardziej komfortowy tabor. W związku z coraz to bardziej zaawansowanymi konstrukcjami i warunkami technicznymi nowoczesnych tramwajów wynika konieczność dopasowania istniejących już wymagań homologacyjnych. Ze statystyk GUS [7] wynika, że w 2014 r. w Polsce z transportu kolejowego skorzystało ponad $268 \mathrm{mln}$ pasażerów, natomiast $\mathrm{z}$ transportu miejskiego (w tym autobusy, tramwaje, trolejbusy i metro) blisko 4 mld pasażerów. Część z liczby 4 mld stanowią pasażerowie tramwajów. Stawia to je w pozycji częściej używanego środka transportu, aniżeli pociagi i elektryczne zespoły trakcyjne, które mają znacznie bardziej restrykcyjne wymagania dotyczące badań homologacyjnych aniżeli tramwaje. Jest to argument stanowiący potwierdzenie dla propozycji zaostrzenia lub zaproponowania dodatkowych wymagań homologacyjnych dla tramwajów w Polsce.

Coraz częściej spotyka się sytuacje gdzie przewoźnicy chcący zakupić nowy tabor wymagają przeprowadzenia dodatkowych badań, poza badaniami homologacyjnymi, spełniających dodatkowe kryteria. Poniżej przedstawiono kilka wybranych aspektów, na które warto zwrócić uwagę, a które nie są wyszczególnione w rozporządzeniach $[1,2]$, obowiązujących podczas badań homologacyjnych tramwajów. Ma to na celu jedynie zasygnalizowanie $\mathrm{w}$ obowiązujących przepisach luk i rozwinięcie ich w kolejnych pracach.

\subsection{Wytrzymałość statyczna, zmęczeniowa i sta- bilność konstrukcji pudla}

W rozporządzeniach $[1,2]$ nie wyszczególniono wymagań dotyczących wytrzymałości konstrukcyjnej 
characteristics should be met by the material. It is assumed that the body should withstand the maximum loads in accordance with their operating requirements and achieve the durability period in the normal operating conditions. Depending on the design, this should be presented by the calculations or tests. To ensure full safety for passengers traveling on a given vehicle, the PN-EN 12663-1 + A1: 2015-01 standard [10] it is specified:

- the special load specifying the maximum load that should be withstood in operating conditions,

- stress coefficients such that the significant loads can occur before any possible crack or deformations occur;

- operation or cyclic loads withstood for a specific durability period without damage for safety of construction;

which should be met for the group of "passenger vehicles" category P-V - tram vehicles. Moreover, the strength tests would give a clear guideline concerning the qualification of a given vehicle for the same type of vehicle or its variant. Regulation [2] says only about "the obvious and basic differences" which are not defined further.

\subsection{Vibrations affecting the driver and passenger riding comfort}

As in the above case, also in this it is not specified in the regulations the conditions that should be met by the vehicle in terms of vibrations affecting the driver and passengers. In the case of a driver, the justification for this type of tests is the long-lasting exposure to unfavorable working conditions, for at least approx. 8 hours a day. In connection with the above, the reference can be made to the Regulation of the Minister of Labor and Social Policy O. J. 2017, item 1348 [4] which specifies the permissible level of vibrations affecting a person during the work. The exceeded levels of vibration values may cause a weakening of the psychophysical fitness of the drivers and have negative health effects, and consequently they may indirectly affect the safety of passengers while riding. More and more frequent practice of the companies ordering vehicles is the containing the requirements from O. J. 2017, item 1348 [4], concerning the vibrations acting on the human body in the Specification of Essential Terms of the Order. This is the basis for placing the similar requirements in the regulation concerning the technical conditions that must be met by the approved vehicle.

The second aspect related to the vibrations and inertia forces is the passenger comfort. Tram passengers are not exposed to a single long-lasting effect on the body, but regular staying in such surroundings may have an adverse effect on the human body. For example, the longest tram line in Poznan is over $15 \mathrm{~km}$, and its time to cover is about 40 minutes. In the case of traveling pudła tramwaju. Producent dostarczając pojazd do badań homologacyjnych nie ma obowiązku dostarczenia dokumentów potwierdzających spełnienie jakiejkolwiek normy dotyczącej wytrzymałości konstrukcyjnej pudła. Tramwaj podczas eksploatacji poddawany jest statycznym i dynamicznym obciążeniom. Należałoby zatem określić, jakie obciążenia powinny wytrzymać konstrukcje nośne pojazdów i jakie cechy powinien spełniać materiał. Zakłada się, że pudło powinno wytrzymywać maksymalne obciążenia zgodne $\mathrm{z}$ ich wymaganiami eksploatacyjnymi i osiągać wymagany okres trwałości w normalnych warunkach eksploatacyjnych. W zależności od konstrukcji powinno być to przedstawione za pomocą obliczeń lub badań. Konstrukcja spełniająca warunek odpowiedniej wytrzymałości powinna wg normy PN-EN 12663-1+A1:2015-01 [10], zostać poddana następującym obciążeniom statycznym:

- szczególne obciążenie określające maksymalne obciążenie, które powinno być wytrzymane w pełnych warunkach eksploatacyjnych

- współczynniki wytężenia takie, aby mogły wystapić istotne obciążenia przed wystapieniem ewentualnego pęknięcia lub odkształcenia

- eksploatację lub cykliczne obciążenia wytrzymywane dla określonego okresu trwałości bez uszczerbku dla bezpieczeństwa konstrukcji,

które powinny być spełnione dla grupy ,pojazdy pasażerskie" - kategoria P-V pojazdy tramwajowe. Ponadto badania wytrzymałościowe dałyby jednoznaczną wytyczną dotyczącą kwalifikowania danego pojazdu do tego samego typu pojazdu lub jego wariantu. Rozporządzenie [2] mówi bowiem wyłącznie o „oczywistych i podstawowych różnicach” których dalej nie zdefiniowano.

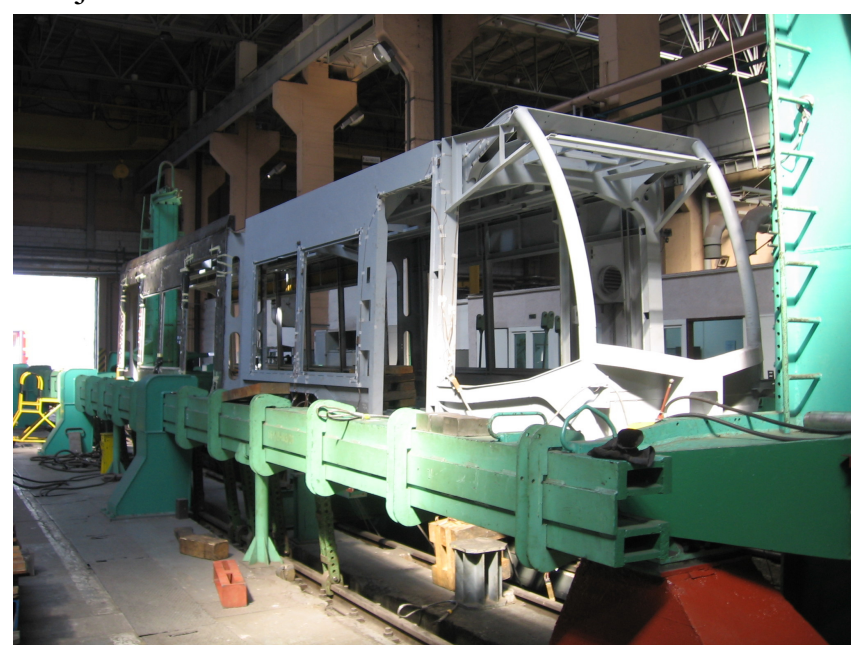

Fig. 2. View of the construction of the tram body during static strength tests

Rys. 2. Widok konstrukcji pudła tramwaju podczas statycznych badań wytrzymałościowych

\subsection{Drgania oddziałujące na motorniczego i kom-} fort jazdy pasażerów

Również w tym przypadku nie określono w rozporządzeniach warunków, 
the entire route twice a day, it is already about one and a half hours a day. Summing up this time for a month gives more than a day of human being in the unfavorable conditions. In this aspect, it can be used a standard intended to the railways, where passengers pay more and more attention to the comfort of traveling. The PN-EN 12299: 2009 [11] standard can also be applied to trams. In order to make the public transport in the form of trams more attractive, competitive and safe, it should be considered to introduce such requirements to the order specifications, or to documents concerning the technical conditions that should be met by the homologated tram.

\subsection{Noise in the driver's cab}

As in the case of vibrations affecting the driver while riding, it also should be paid attention to the level of noise he is exposed to. In O. J. 2011, No. 65, item 344 [1] the requirements concerning the noise generated by the vehicle to the environment are only contained. In the railways the requirements for the driver's cab have also been extended. In the tram, the element, that generates the most noise, is the wheel-rail contact. It can be assumed that the undesired sources of sound are installed devices in the vehicle (e.g. air conditioning) and the sound generated by the warning device. Too long stay in a place, where you can be exposed to an adverse effect of acoustic pressure, may cause deterioration of the operator's working conditions and psycho-physical fitness. It is also proved the catastrophic impact of vibroacoustics on the human body. Noise is one of the main causes of occupational diseases of transport operators such as partial or complete hearing loss [9]. In the case of drivers, hygiene and working conditions are directly correlated with passenger safety. Also the acoustic pressure values in the driver's cab can be referred to the Regulation of the Minister of Labor and Social Policy (O. J. 2017, item 1348) [4]. Therefore, increasing the technical conditions, that the approved tram must meet with fulfillment of the noise requirements in the driver's cabin, should be considered.

\subsection{Braking from the maximum speed with the load.}

One of the most important systems in the vehicles, not only rail ones, is the braking system. It is responsible for safe, collision-free vehicle stop. Trams according to O. J. 2011, No. 65, item 344 [1] must be equipped with the electrodynamic, mechanical and rail brakes. The basic test of the braking system in the tram is to determine the delay value and to measure the braking distance from a speed of $30 \mathrm{~km} / \mathrm{h}$ for a service brake, sudden brake and emergency brake. In the railway the brake tests are much more complicated and they are depended directly on the type of vehicle. However, the most important difference is the brake test from jakie powinien spełniać pojazd pod względem drgań oddziałujących na motorniczego i pasażerów. W przypadku motorniczego uzasadnieniem dla tego typu badań jest długotrwałość narażenia na niekorzystne warunki pracy, przez przynajmniej ok. 8 godzin dziennie. W związku z powyższym można odnieść się do Rozporządzenia Ministra Pracy i Polityki Społecznej Dz. U. 2017 r., poz. 1348 [4], w którym określono dopuszczalny poziom drgań oddziałujących na człowieka podczas pracy. Przekroczone poziomy wartości drgań mogą powodować osłabienie sprawności psychofizycznej motorniczych oraz mieć negatywne skutki zdrowotne, a co za tym idzie moga pośrednio wpływać na bezpieczeństwo pasażerów podczas jazdy. Coraz częstszą praktyką zamawiających pojazdy jest stawianie wymagań z Rozporządzenia (Dz. U. 2017 r., poz. 1348 [4]), dotyczących drgań działających na organizm człowieka w Specyfikacji Istotnych Warunków Zamówienia. Jest to podstawą do zamieszczenia podobnych wymagań w rozporządzeniu dotyczącym warunków technicznych jakie musi spełniać homologowany pojazd.

Drugim aspektem związanym z drganiami i siłami bezwładności jest komfort jazdy pasażerów. Pasażerowie tramwaju nie są narażeni na jednorazowy długotrwały ich wpływ na organizm, jednak regularne przebywanie $\mathrm{w}$ takim otoczeniu może mieć niekorzystny wpływ na organizm człowieka. Dla przykładu najdłuższa linia tramwajowa w Poznaniu wynosi ponad $15 \mathrm{~km}$, a czas jej pokonania wynosi ok 40 minut. W przypadku przejazdu całej trasy dwa razy dziennie jest to już ok. półtorej godziny dziennie. Zsumowanie tego czasu na przestrzeni miesiąca daje ponad dobę przebywania człowieka $\mathrm{w}$ warunkach nie korzystnych. W tym aspekcie posłużyć się można normą dedykowaną dla kolejnictwa, gdzie coraz większą uwagę zwraca się na komfort podróżowania pasażerów. Normę PN-EN 12299:2009 [11] można również zastosować w odniesieniu do tramwajów. Aby publiczny transport miejski w postaci tramwajów był coraz bardziej atrakcyjny, konkurencyjny i bezpieczny, należy rozważyć wprowadzenie takich wymogów do specyfikacji zamówienia lub do dokumentów dotyczących warunków technicznych, jakie powinien spełniać homologowany tramwaj.

\subsection{Hałas w kabinie motorniczego}

Podobnie jak w przypadku drgań oddziałujących na motorniczego podczas jazdy, należy również zwrócić uwagę na poziom hałasu na jaki jest on narażony. W Dz. U. 2011 r., nr 65, poz. 344 [1] zamieszczono wyłącznie wymagania dotyczące hałasu generowanego przez pojazd do otoczenia. W kolejnictwie rozszerzono to również o wymagania dotyczące kabiny maszynisty. W tramwaju elementem generującym najwięcej hałasu jest styk koło-szyna. Kolejno można przyjąć, że źródłami dźwięku niepożądanego są zainstalowane urządzenia w pojeździe (np. klimatyzator) oraz 
the maximum speed that the vehicle can reach. In Poland, the trams can move on some sections even at a speed of $70 \mathrm{~km} / \mathrm{h}$. Another important issue is the fact that currently the approval tests of the braking system are carried out with the unloaded vehicle. Reality often shows that the public transport vehicles are overcrowded, especially during rush hours.

In the case of the tram with a maximum load, the braking distance may be longer than in the case of an empty tram. The argument for determining the requirements concerning the length of braking distances in the section of the track with the reduced adhesion between the wheel and the rail may be the event of 2011. from Poznań. In this case the atmospheric rainfalls and freshly cut grass made 47 passengers to be injured. In O. J. 2011. No. 65, item 344 [1] it is described the requirement for a functional check of the anti-skid device operation. On this example it can also be stated that it is necessary to determine the requirements concerning the length of braking distances on the section of the track with the reduced adhesion between the wheel and rail $[16,18]$.

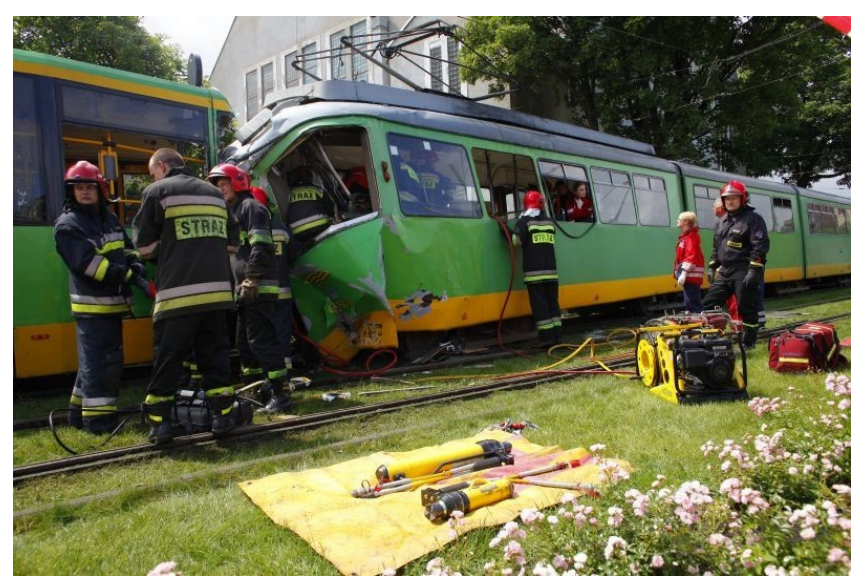

Fig. 3 View of the tram after the collision of 2011 at Poznan Garbary [18]

Rys. 3 Widok tramwaju po kolizji z 2011 r. na poznańskich Garbarach [18]

\subsection{Heating and air - conditioning}

The operational comfort of the rail vehicle operator is an important element in ensuring the safety of travelers. To ensure the proper working conditions of the driver, the right temperature during work, so the efficient operation of air - conditioning and heating can be numbered. In the railways, the requirements for air - conditioning and heating for the driver are included in the PN-EN 14813-1 + A1: 2011 standard and PN-EN 14813-2 + A1: 2011 standard [13, 14]. These standards may also apply to the trams according to their scope of application. Identically as in the above cases, the technical requirements for heating/air conditioning in the approval conditions of trams are not described. Therefore, it is reasonable to introduce these requirements to the Regulation of the Minister of Infrastructure regarding the technical dźwięk generowany przez urządzenie ostrzegawcze. Zbyt długie przebywanie w miejscu, w którym jest się narażonym na niekorzystny wpływ ciśnienia akustycznego, może powodować pogorszenie warunków pracy i sprawności psycho-fizycznej operatora. Dowodzi się również katastrofalnego wpływu wibroakustyki na organizm człowieka. Hałas jest jedną z głównych przyczyn chorób zawodowych operatorów środków transportu, takich jak częściowa lub pełna utrata słuchu [9]. Higiena i warunki pracy, w przypadku motorniczych, są bezpośrednio skorelowane $\mathrm{z}$ bezpieczeństwem pasażerów. Również wartości ciśnienia akustycznego w kabinie motorniczego można odnieść do Rozporządzenia Ministra Pracy i Polityki Społecznej (Dz. U. 2017 r., poz. 1348) [4]. Należy zatem rozważyć wzbogacenie warunków technicznych, jakim musi odpowiadać homologowany tramwaj o spełnienie wymogów dotyczących hałasu w kabinie motorniczego.

\subsection{Hamowanie $\mathrm{z}$ prędkości maksymalnej $\mathrm{z}$ obcią- żeniem.}

Jednym z najważniejszych układów w pojazdach, nie tylko szynowych, jest układ hamulcowy. Odpowiada on za bezpieczne, bezkolizyjne zatrzymanie pojazdu. Tramwaje, zgodnie z Dz. U. 2011 r., nr 65, poz. 344 [1], muszą być wyposażone $\mathrm{w}$ hamulec elektrodynamiczny, mechaniczny i szynowy. Podstawowym badaniem układu hamulcowego w tramwaju jest wyznaczenie wartości opóźnienia oraz pomiar długości drogi hamowania z prędkości $30 \mathrm{~km} / \mathrm{h}$ dla hamulca roboczego, nagłego, bezpieczeństwa oraz awaryjnego. W kolejnictwie badania hamulca są znacznie bardziej skomplikowane i uzależnione są bezpośrednio od rodzaju pojazdu. Najważniejszą jednak różnicą są badania hamulca $\mathrm{z}$ prędkości maksymalnej, jaką może osiagnąć pojazd. W Polsce tramwaje mogą poruszać się na niektórych odcinkach nawet z prędkością 70 $\mathrm{km} / \mathrm{h}$. Kolejną istotną kwestią jest fakt, że obecnie badania homologacyjne układu hamulcowego odbywają się przy nieobciążonym pojeździe. Rzeczywistość nierzadko pokazuje, że pojazdy komunikacji miejskiej są przepełnione, zwłaszcza $\mathrm{w}$ godzinach szczytu. W przypadku tramwaju maksymalnie obciążonego droga hamowania może się wydłużyć w stosunku do tramwaju pustego. Argumentem przemawiającym za określeniem wymagań dotyczących długości dróg hamowania na odcinku toru o obniżonej przyczepności pomiędzy kołem a szyną, może być wypadek w 2011 r. w Poznaniu. Opady atmosferyczne i świeżo skoszona trawa były powodem wypadku, w którym zostało poszkodowanych 47 pasażerów. W Dz. U. 2011 r., nr 65, poz. 344 [1] opisano wymaganie dotyczące funkcjonalnego sprawdzenia działania urządzenia przeciwpoślizgowego. Na tym przykładzie można również stwierdzić, że konieczne jest określenie wymagań dotyczących długości dróg hamowania na odcinku toru o obniżonej przyczepności pomiędzy kołem a szyną $[16,18]$. 
conditions of trams and trolleybuses and the scope of their necessary equipment [1]. In addition, only functionally, it is recommended to check the operation of heating and air - conditioning in the passenger compartment. Due to the fact that the tram moves on short distances, each time at the stop opening the door, then the heat exchange is completely different than in the case of railway vehicles and there is no constructive justification for the application of railway requirements to the tram rolling stock.

\subsection{Others}

Documents related to the approval of trams in Poland do not yet describe a few issues that should be considered in the requirements. An example it may be the lack of requirements concerning the used friction linings, the lack of requirements for the proper wheels loads on the rail (maximum deviations relative to vehicle sides, vehicle axles, etc.), lack of checking the passenger information intelligibility system, the updating the requirements concerning the unified gauge of the vehicle. All these components can directly or indirectly affect the safety of travelers.

\section{Conclusions}

At present, in large cities or urban agglomerations it is aspired to encourage the individual transport users to use the mass urban transport. Due to the fact that trams, theoretically, do not participate in congestion, it allows to state that they are faster means of transport than buses, with the disadvantage that they will only reach the places where the tram infrastructure is brought. However, in order to make the urban rail transport more competitive, it must be not only more comfortable but, above all, safer for passengers and service. Therefore, it is reasonable to tighten regulations and requirements allowing the vehicle to be used in Poland. Another constructive argument for extending the scope of tests and approval requirements is the number of passengers carried annually, which in 2014. was 4 billion by all means of urban transport in Poland [7]. At the moment, the extension of the requirements authorizing the tram vehicle for placing into service and improving its parameters are forced by the customers to producers. First of all, it should be asked whether the vehicles produced for Polish transport companies are completely safe and the demanded requirements for trams are sufficient to determine this?. At present the regulations are unequally focused on various elements of the vehicle, for example checking the external lighting is much more extensive than checking the level of acoustic pressure generated by the vehicle outside during the movement. Moreover, the question should be asked why acoustic tests are carried out at a speed of $50 \mathrm{~km} / \mathrm{h}$, but the tests of the brake - the most important system in the vehicle - only from $30 \mathrm{~km} / \mathrm{h}$ [1]?. The purpose of the above considerations is

\subsection{Ogrzewanie i klimatyzacja}

Komfort pracy operatora pojazdu szynowego jest istotnym elementem zapewnienia bezpieczeństwa podróżujących. Do zapewnienia odpowiednich warunków pracy motorniczego można zaliczyć odpowiednią temperaturę podczas pracy, a więc wydajną klimatyzację i ogrzewanie. W kolejnictwie wymagania dotyczace klimatyzacji i ogrzewania dla maszynisty zawarto w normie PN-EN 14813-1+A1:2011 oraz PNEN 14813-2+A1:2011 [13, 14]. Normy te moga odnosić się również do tramwajów, zgodnie z ich zakresem stosowania. Identycznie jak w powyższych przypadkach nie opisano wymagań technicznych dotyczących ogrzewania/klimatyzacji w warunkach homologacyjnych tramwajów.

Uzasadnione jest zatem wprowadzenie tych wymagań do Rozporządzenia Ministra Infrastruktury w sprawie warunków technicznych tramwajów i trolejbusów oraz zakresu ich niezbędnego wyposażenia [1]. Dodatkowo, jedynie funkcjonalnie, zaleca się sprawdzenie działania ogrzewania i klimatyzacji w przedziale pasażerskim. $Z$ uwagi na to, że tramwaj porusza się na krótkich odcinkach, każdorazowo na przystanku otwierane są drzwi, wówczas wymiana ciepła przebiega zupełnie odmiennie niż w przypadku pojazdów kolejowych i nie ma konstruktywnego uzasadnienia stosowania wymagań kolejowych do taboru tramwajowego.

\subsection{Pozostale}

Dokumenty związane $\mathrm{z}$ homologacją tramwajów w Polsce nie opisują jeszcze kilku kwestii, których uwzględnienie w wymaganiach należałoby rozważyć. Przykładem może być brak wymagań dotyczących stosowanych okładzin ciernych, brak wymagań dotyczących odpowiedniego rozkładu nacisków kół na szynę (maksymalne odchylenia względem stron pojazdu, względem osi pojazdu itp.), brak sprawdzenia systemu zrozumiałości mowy informacji pasażerskiej, aktualizacja wymagań dotyczących ujednoliconej skrajni pojazdu. Wszystkie te składniki bezpośrednio lub pośrednio mogą wpływać na bezpieczeństwo podróżujących.

\section{Podsumowanie}

Obecnie, w dużych miastach lub aglomeracjach miejskich dąży się do zachęcenia użytkowników transportu indywidualnego do korzystania ze zbiorowego transportu miejskiego. W związku z tym, że teoretycznie tramwaje nie uczestniczą w kongestii, pozwala to na stwierdzenie, że są szybszym środkiem transportu niż autobusy, z tą wada, że dotrą wyłącznie do miejsc, do których doprowadzona jest infrastruktura tramwajowa. Aby jednak miejski transport szynowy był coraz bardziej konkurencyjny, musi być nie tylko bardziej komfortowy, ale przede wszystkim coraz bezpieczniejszy dla pasażerów i obsługi. Wobec tego zasadne jest zaostrzenie przepisów i wymagań dopuszczających pojazd do użytkowania w Polsce. 
preparing the further works clarifying the proposals of changing the approval requirements for trams in Poland.

\section{Bibliography / Literatura}

[1] Dz. U. $2011 \mathrm{r}, \mathrm{nr}$ 65, poz. 344. Rozporzqdzenie Ministra Infrastruktury $z$ dnia 2 marca $2011 \mathrm{r}$. w sprawie warunków technicznych tramwajów $i$ trolejbusów oraz zakresu ich niezbędnego wyposażenia;

[2] Dz. U. $2015 r$., poz. 38. Rozporzadzenie Ministra Transportu, Budownictwa i Gospodarki Morskiej w sprawie homologacji typu tramwajów i trolejbusów.

[3] Dz.U. 1997 Nr 98 poz. 602. Ustawa Prawo o Ruchu Drogowym.

[4] Dz. U. 2017 r., poz. 1348. Rozporzqdzenie Ministra Pracy i Polityki Spolecznej w sprawie najwyższych dopuszczalnych stężeń $i$ natężeń czynników szkodliwych dla zdrowia w środowisku pracy.

[5] Dz. U. 2011 r., $n r$ 65, poz. 343. Rozporzadzenie Ministra Infrastruktury $w$ sprawie zakresu, warunków, terminów i sposobu przeprowadzania badań technicznych tramwajów i trolejbusów oraz jednostek wykonujacych te badania.

[6] Europejska Komisja Gospodarcza Organizacji Narodów Zjednoczonych Regulamin 107. Jednolite Przepisu dotyczace homologacji pojazdów kategorii M2 i M3 w odniesieniu do ich budowy ogólnej.

[7] Gtówny Urzqd Statystyczny. Rocznik Statystyczny Rzeczypospolitej Polskiej. Warszawa 2015 r.

[8] Królikowski J., Cichy R., Kowalski M. Tramwaje proces homologacji $w$ kontekście ochrony środowiska. Pojazdy Szynowe 2017 r., nr 3;

[9] Nader M., Purta E. Ocena narażenia czlowieka na oddzialywanie drgań $i$ hałasu $w$ pojazdach szynowych. Problemy Eksploatacji 2003 r., $n r 2$.

[10] PN-EN 12663-1+A1:2015-01. Kolejnictwo -Wymagania konstrukcyjno-wytrzymałościowe dotyczace pudet kolejowych pojazdów szynowych -Czesśc 1: Lokomotywy i tabor pasażerski (i metoda alternatywna dla wagonów towarowych).

[11] PN-EN 12299:2009. Kolejnictwo -- Komfort jazdy pasażerów -- Pomiary i ocena.

[12] PN-EN 13272:2012. Kolejnictwo -- Oświetlenie elektryczne pojazdów szynowych $w$ systemach transportu publicznego.

[13] PN-EN 14813-1+A1:2011. Kolejnictwo -Klimatyzacja kabin maszynisty -- Część 1: Parametry komfortu.

[14] PN-EN 14813-2+A1:2011. Kolejnictwo -Klimatyzacja kabin maszynisty -- Część 2: Badania typu.

[15] PN-EN 50121-3-1:2017. Zastosowania kolejowe Kompatybilność elektromagnetyczna - Część 3-1: Tabor - Pociag i kompletny pojazd.

[16] Przepióra K., Szuberski P. Badania układów hamulcowych pojazdów tramwajowych $w$ aspekcie homologacji tramwajów. Pojazdy Szynowe 2017 r. $n r$;
Kolejnym konstruktywnym argumentem za tym, aby rozszerzyć zakres badań i wymagań homologacyjnych jest ilość przewożonych rocznie pasażerów, która wynosiła w 2014 r., 4 mld wszystkimi środkami transportu miejskiego w Polsce [7]. W chwili obecnej rozszerzenie wymagań dopuszczających pojazd tramwajowy do ruchu oraz poprawienie jego parametrów wymusza na producentach klient.

Należy zadać sobie przede wszystkim pytanie, czy pojazdy produkowane dla polskich przedsiębiorstw komunikacyjnych są w pełni bezpieczne i czy wymagania stawiane tramwajom są wystarczające, aby to określić. Aktualne przepisy nierównomiernie skupiają się na różnych elementach pojazdu, dla przykładu sprawdzenie oświetlenia zewnętrznego jest dużo bardziej rozbudowane niż sprawdzenie poziomu ciśnienia akustycznego, jakie generuje pojazd na zewnątrz podczas ruchu. Ponadto należy zadać pytanie dlaczego badania akustyczne przeprowadza się z prędkości $50 \mathrm{~km} / \mathrm{h}$, natomiast badania hamulca - najważniejszego układu w pojeździe, zaledwie z $30 \mathrm{~km} / \mathrm{h}$ [1].

Powyższe rozważania mają na celu przygotowanie dalszych prac uściślających propozycje zmiany wymagań homologacyjnych tramwajów w Polsce.

[17] RFU PRM 053 Assessment of conformity concerning contrast - alternative measure for contrast identification. NB-Rail 2010

[18] http://poznan.naszemiasto.pl/artykul/poznanwypadek-tramwajowy-na-garbarach-motorniczyskazany, 1798996,artgal,t,id,tm.html

[19] https://poznan.onet.pl/czego-nie-wiesz-opoznanskiej-komunikacji/7794vn

[20] https://epoznan.pl/news-news-55637 Ilu_pasazerow_rocznie_jezdzi_komunikacja_miejska Poznanskie_MPK_w_liczbach

[21] $\bar{h}$ ttps://www.trojmiasto.pl/wiadomosci/Rosnieliczba-pasazerow-tramwajow-i-autobusow-wGdansku-n109699.html

[22] http://www.kmpk.cba.pl/galeria-beta-bd.html

[23] http://infotram.pl/tramwaj-w-edynburgu-budowa-iprzebieg trasy_more_37497.html

[24] https://pl.wikipedia.org/wiki/Tramwaje_w_Olsztynie

[25] http://www.gs24.pl/wiadomosci/szczecin/art/546840 4,policzyli-pasazerow-najwiecej-jezdzi-tramwajem12-i-autobusem-75,id,t.html

[26] https://tw.waw.pl/zamowienia-publiczne/zakuptramwajow-jednokierunkowych-i-dwukierunkowychwieloczlonowych-calkowicie-niskopodlogowych/

[27] http://www.mpk.czest.pl/przetargi/archiwum/2017

[28] http://www.tram-

silesia.pl/www/index.php/32996/uejrpb4542017/ 